\title{
IMPLEMENTASI LOAD BALANCING DENGAN METODE EQUAL COST MULTI-PATH
}

\author{
Muhammad Fauzi Zurkarnaen ${ }^{1}$, M. Iqbal Isnaini ${ }^{2}$ \\ Teknik Informatika, STMIK Lombok \\ Jln. Basuki Rahmat No. 105. Praya Lombok Tengah 83511 \\ 1auzi tuan@yahoo.com, ${ }^{2}$ Iqbalisnaini14@yahoo.com
}

\begin{abstract}
The availability of the Internet has already become a staple menu for business and educational institutions, one of which high school management informatics and computer (STMIK) Lombok, its role is already included in the category of primary from high school is, unfortunately, the Internet is today was still not reliable because it is often experiencing a lost connection to the network. This is quite disturbing and can degrade the performance of the object.

Ideally, high school today must have an Internet network that reliably and can fulfill their role on an ongoing basis, is no exception tissue in the lab campus STMIK Lombok, and in cases like this there are some ways that can be applied either by replacing existing ISP today with the more reliably, or implement load balancing features for performance of load balancing is helpful in two consummation of a connection that is more stable due to the function of load banlance itself is used to divide the load (load) into multiple lines (links) so, the authors decided to propose solution in the form of two ISPs' internet network by means of load balancing using Equal Cost Multi-Path (ECMP) to resolve the above problems.
\end{abstract}

Keywords : Load Balancing, Equal Cost Multi-Path

\section{Abstrak}

Ketersediaan internet kini sudah menjadi menu pokok bagi penggelut bisnis maupun lembaga pendidikan, salah satunya sekolah tinggi manajemen informatika dan komputer (STMIK) Lombok, perannya sudah masuk dalam katagori primer dari sekolah tinggi tersebut, sayangnya jaringan internet yang sekarang ini terasa masih kurang andal karena kerap mengalamai lost connection pada jaringannya. Hal ini cukup mengganggu dan dapat menurunkan kinerja dari objek.

Idealnya, sekolah tinggi masa kini harus memiliki jaringan internet yang andal dan dapat menjalankan perannya secara berkesinambungan,tidak terkecuali jaringan di lab kampus STMIK Lombok, dan dalam kasus seperti ini ada beberapa cara yang dapat diterapkan salah satunya dengan mengganti ISP yang ada saat ini dengan yang lebih andal, atau mengimplementasikan fitur load balancing karena kinerja dari load balance sangat membantu dalam dua penyempurnaan suatu koneksi yang lebih stabil dikarenakan fungsi dari load banlance itu sendiri digunakan untuk membagi beban (load) ke dalam beberapa jalur (link) sehingga, peneliti memutuskan untuk mengusulkan solusi berupa jaringan internet dua ISP `dengan cara load balancing menggunakan Equal Cost Multi Path (ECMP) untuk menyelesaikan permasalahan di atas.

Kata Kunci : Load Balancing, Equal Cost Multi Path

\section{Pendahuluan}

Pada saat ini kebutuhan internet sudah sangat tinggi, bahkan bisa di bilang semua orang yang sudah mengerti teknologi membutuhkan koneksi internet, baik untuk mencari informasi, artikel maupun pengetahuan terbaru. Seiring dengan bertambahnya pengguna internet tersebut, agar jaringan benar benar optimal, selain pengaturan IP address perlu juga dilakukan pengaturan routing. Device yang digunakan untuk proses routing disebut router. Namun karena harga dari router relatif mahal, oleh karena itu ada alternatif hardware lain yaitu Mikrotik Router OS merupakan sistem operasi yang mampu membuat komputer menjadi router atau sering disebut PC Router. Sistem operasi tersebut mencakup berbagai fitur lengkap untuk wireline 
dan wireless, antara lain adalah bandwidth management, proxy server, hotspot, load balancing dan sebagainya. Di samping itu ketersediaan internet kini sudah menjadi menu pokok bagi penggelut bisnis maupun lembaga pendidikan, salah satunya sekolah tinggi manajemen informatika dan komputer (STMIK) Lombok, perannya sudah masuk dalam katagori primer dari sekolah tinggi tersebut, sayangnya jaringan internet yang sekarang ini terasa masih kurang andal karena kerap mengalamai lost connection pada jaringannya. Hal ini cukup mengganggu dan dapat menurunkan kinerja dari objek.

Idealnya, sekolah tinggi masa kini harus memiliki jaringan internet yang andal dan dapat menjalankan perannya secara berkesinambungan,tidak terkecuali jaringan di lab kampus STMIK Lombok, dan dalam kasus seperti ini ada beberapa cara yang dapat diterapkan salah satunya dengan mengganti ISP yang ada saat ini dengan yang lebih andal, atau mengimplementasikan fitur load balancing karena kinerja dari load balance sangat membantu dalam dua penyempurnaan suatu koneksi yang lebih stabil dikarenakan fungsi dari load banlance itu sendiri digunakan untuk membagi beban (load) ke dalam beberapa jalur (link) sehingga, peneliti memutuskan untuk mengusulkan solusi berupa jaringan internet dua ISP 'dengan cara load balancing menggunakan Equal Cost Multi Path (ECMP) untuk menyelesaikan permasalahan di atas. Penggunakan dua ISP dan menjadikan mikrotik sebagai load balancer yang diharapkan juga mikrotik dapat mengoptimalkan pembagian bandwidth pada setiap client yang ingin mengakses internet. Mekanismenya yaitu mikrotik akan menandai paket yang ingin mengakses internet, lalu menyetarakan beban pada kedua ISP dan akan memilih jalur ISP yang akan dilewatinya.

\section{Tinjuan Pustaka}

Menurut Budi Asyanto dalam skripsinya yang berjudul "Perancangan dan Pembuatan Load Balancing Pada Clustering Web Server Menggunakan LVS" (Studi Kasus) ditemukan bahwa Penggunaan server LVS dapat meningkatkan nilai throughput dibandingkan dewngan menggunakan server tunggal dimana pada server tunggal mempunyai nilai troughput sebesar $10 \mathrm{Kbps}$ sedangkan untuk server LVS mempunyai nilai sebesar 20 Kbps baik menggunakan provider smart maupun indosatm2.

Menurut Habib Burhanudin Yusuf (2016) dalam skripsinya "Analisa dan Perancangan Load Balancing Dengan Metode EMPC Menggabungkan Dua Modem ADSL dan USB", mengatakan bahwa proses load balancing sebenarnya merupakan proses fleksibel yang dapat diciptakan dengan cara dan metode. Proses ini tidak dapat dilakukan oleh sebuah perangkat tertentu atau sebuah software khusus saja, penelitiannya juga menyimpulkan bahwa cukup banyak cara dan pilihan untuk mendapatkan jaringan yang dilengkapi dengan sistem load balancing.

Dan menurut Andri Dwi Utomo (2011) dalam skripsinya yang berjudul "Implementasi Load Balancing Dua ISP Menggunakan Mikrotik" (Studi Kasus: Laboratorium Komputer SMK PGRI Bekasi) ditemukan bahwa Penerapan Nth load balancing telah memberikan bandwidth yang optimal, namun load balancing tidak dapat mengakumulasi besar bandwidth kedua koneksi, karena teknik load balancing bukan berarti $1+1=2$ melainkan $1+1=1+1$

\section{Metodologi Penelitian}

Metode yang digunakan peneliti dalam penelitian ini adalah metode pengumpulan data, metode analisis data dan metode pengembangan sistem.

Metode Pengumpulan data merupakan metode yang digunakan peneliti dalam melakukan penelitian dan menjadikannya informasi yang akan digunakan untuk mengetahui permasalahan yang dihadapi. Metode tersebut meliputi : observasi, studi literatur, dan wawancara. Pada tahap ini analisa masalah yang dimulai dengan tahap mengidentifikasi masalah, memahami cara kerja equal cost multi path (ECMP), menganalisa dan membuat laporan tentang hasil algoritma, menggambarkan sistem menggunakan flowchart. Sedangkan pada tahap pengembangan dilakukan perancangan Load Balancing dengan metode equal cost multi path (ECMP) dan topologi jaringan yang digunakan, termasuk didalamnya yaitu flowchart dan perancangan pengembangan sistem jaringan menggunakan network devlopment life cycle (NDLC).

Dalam tahap penerapan atau implementasi akan mengimplementasikan spesifikasi hasil perancangan pengembangan dan simulasi jaringan Load Balancing dengan metode equal cost multi path (ECMP) menggunakan aplikasi GNS3 dan aplikasi Winbox untuk meremot mikrotik pada usulan pengembangan jaringan di lab kampus STMIK Lombok.

\section{Hasil dan Pembahasan \\ A. Deskripsi Perusahaan}

Perkembangan teknologi informatika dan komputer di Indonesia pada umumnya dan khususnya Lombok Tengah yang merupakan 
basis perekonomian Provinsi Nusa Tenggara Barat adalah suatu keharusan untuk mengantisipasi paradigma baru globalisasi dan otonomi daerah, dimana Lombok Tengah akan memasuki era perdagangan bebas. Dalam situasi seperti ini, daya saing akan sangat tergantung pada kemampuan dalam pengelolaan dan pemanfaatan teknolgi informatika dan komputer. Untuk mengantisipasi hal ini, telah muncul tekad yang sungguh-sungguh dari pemerintah daerah dalam pengembangan telematika yang berbasis komputer.

\section{B. Perancangan Pengembangan Jaringan Yang di Usulkan}

Berikut rancangan yang diusulkan setelah penggunaan mikrotik dan meload balancing jaringan dua ISP dengan menggunakan metode Equal Cost Multi Path (ECMP)

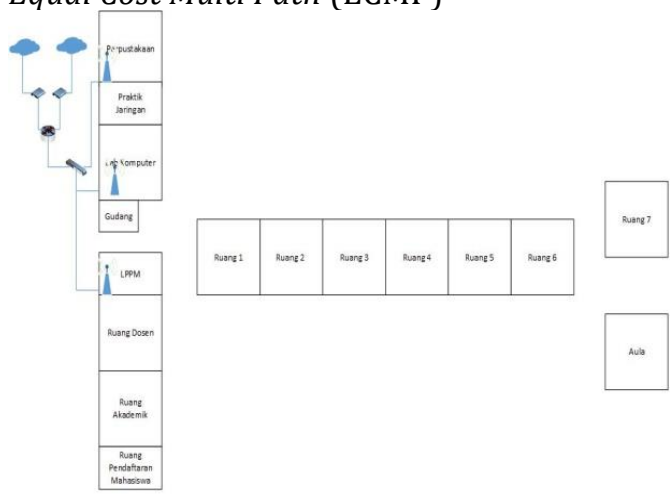

Gambar 1 Jaringan yang diusulkan

Algoritma Equal Cost Multi Path

Pemilihan jalur koneksi ketika ISP 1 mengalami down akan beralih ke ISP 2

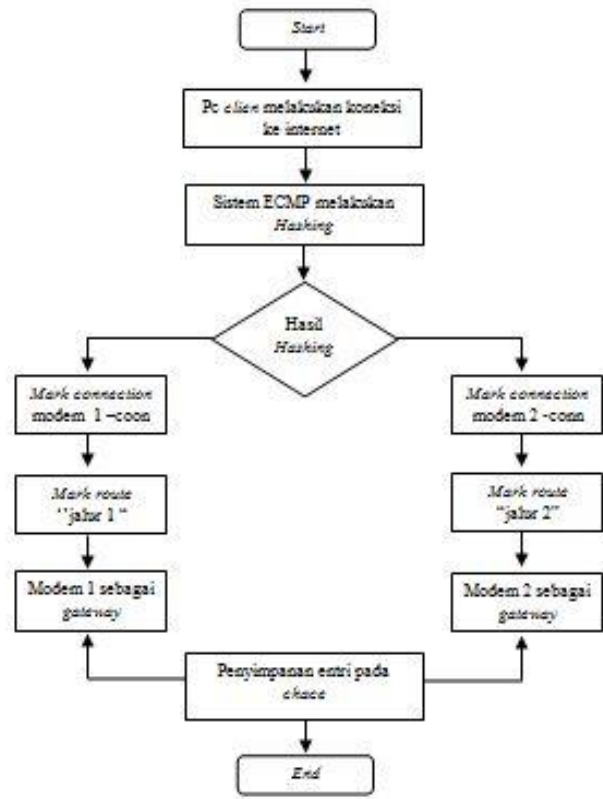

Gambar 2 algoritma ECMP

\section{Implementasi Dan Pembahasan}

Pada tahap ini dilakukan penerapan dari hasil dan analisa, desain dan simulasi jaringan telah dilakukan

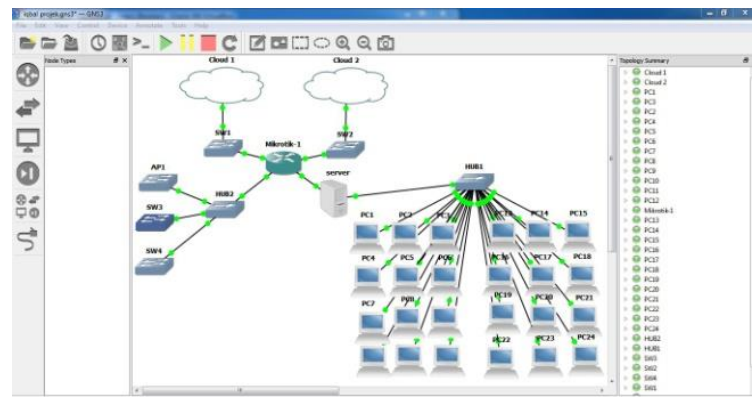

Gambar 3 simulasi jaringan usulan

Tes Ping

Tes Interface ISP 1 dan ISP 2 aktif dan ketika ping google.com akan berhasil

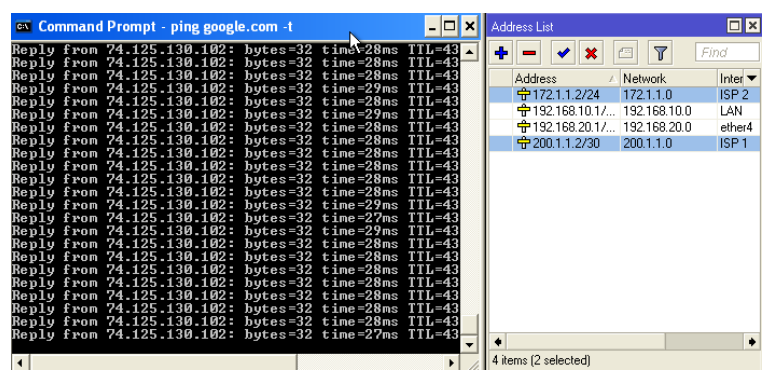

Gambar 4 tes kedua ISP aktif

Tes interface ISP 1 dan ISP 2 tidak aktif dan ketika ping google.com tidak akan berhasil.

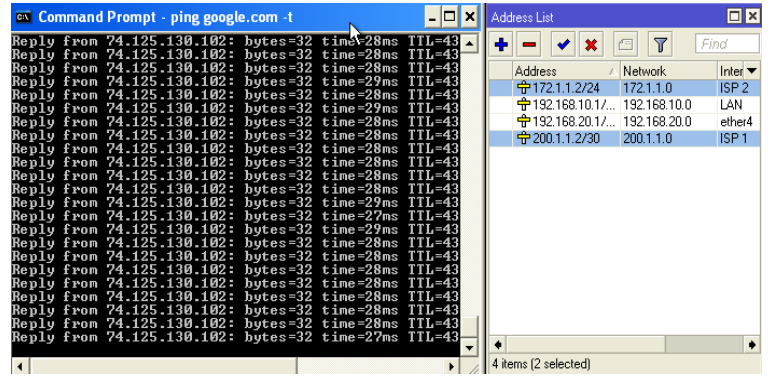

Gambar 5 kedua ISP didak aktif

Tes Interface ISP 1 aktif dan ISP 2 tidak aktif dan ketika ping google.com akan berhasil. Internet akan mengarah ke jalur ISP 1

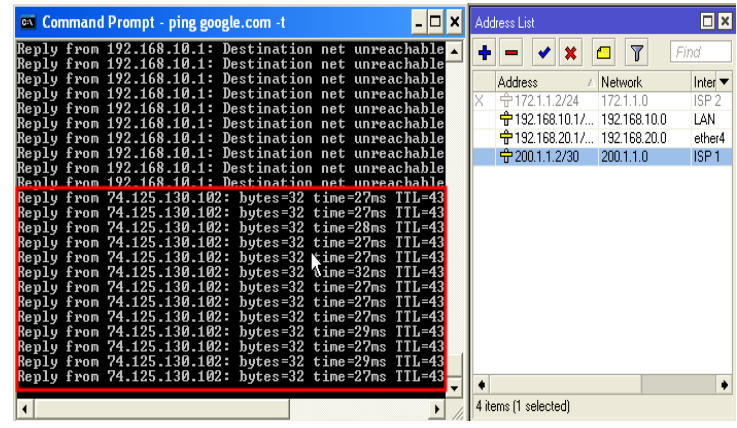

Gambar 6 hanya ISP 1 yang aktif 
Tes Interface ISP 1 tidak aktif dan ISP 2 aktif dan ketika ping google.com akan berhasil. Internet akan mengarah ke jalur ISP 2

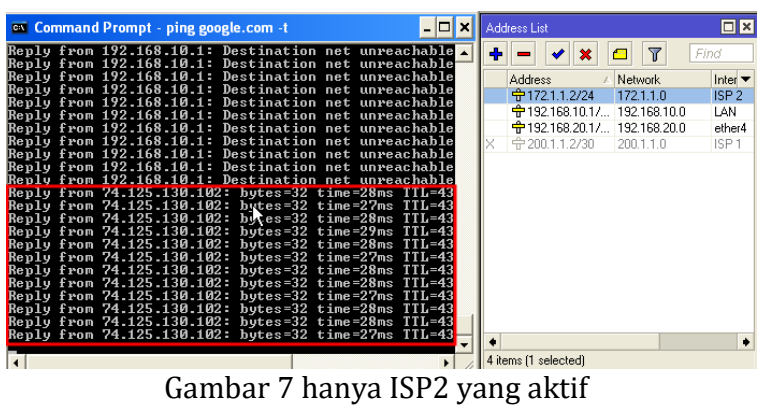

Monitoring (Pengawasan)

Monitoring (pengawasan) yang dimaksud adalah seorang admin jaringan harus tau kontenkonten apa saja yang biasa di-request oleh pengguna yang dapat dilakukan dengan cara mengaktifkan fungsi proxy pada mikrotik, adapun konfigurasi proxy mikrotik yang dimaksud adalah sebagai berikut:

Pada menu mikrotik klik "IP" > "Web Proxy", pada jendela "Web Proxy Settings" berikan ceklist pada "Enable" dan "Cache On Disk", pada "Cache Administrator" bisa diganti dengan keinginan, pada "Max. Cache Size" bisa dipilih sesuai dengan kebutuhan biasanya "Unlimited", klik "Apply" dan "OK".

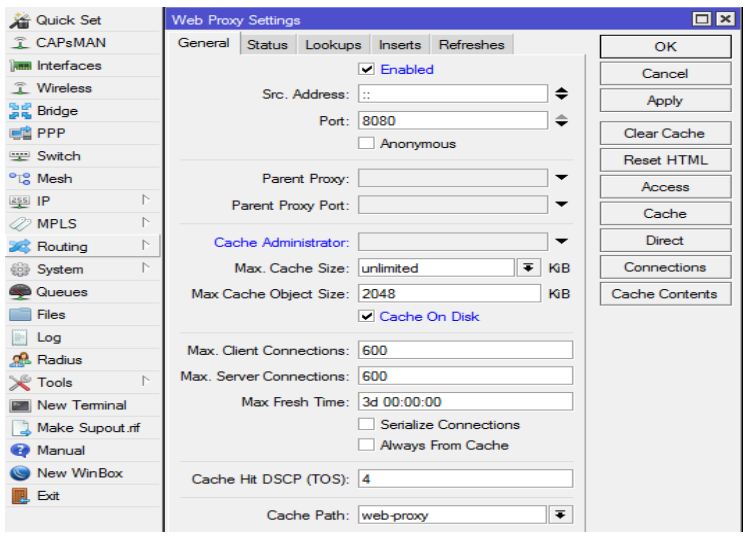

Gambar 8 Konfigurasi Web proxy Mikrotik

\section{Management (Pemeliharaan)}

Pemeliharaan (management) dimaksudkan untuk menjaga keberlansungan, kendala atau masalah dari jaringan yang dibangun, adapun beberapa pemeliharaan yang perlu dilakukan diantaranya. Backup terhadap konfigurasi mikrotik sangat penting untuk dilakukan, apabila suatu waktu konfigurasi pada mikrotik mengalami masalah atau error, maka konfigurasi dari mikrotik dapat di atur ulang (reset) dan di restore kembali. Adapun langkah untuk backup mikrotik adalah klik "File" pada menu mikrotik, pada jendela "File List" klik "Backup", setelah itu paste file backup mikrotik di direktori yang diinginkan.

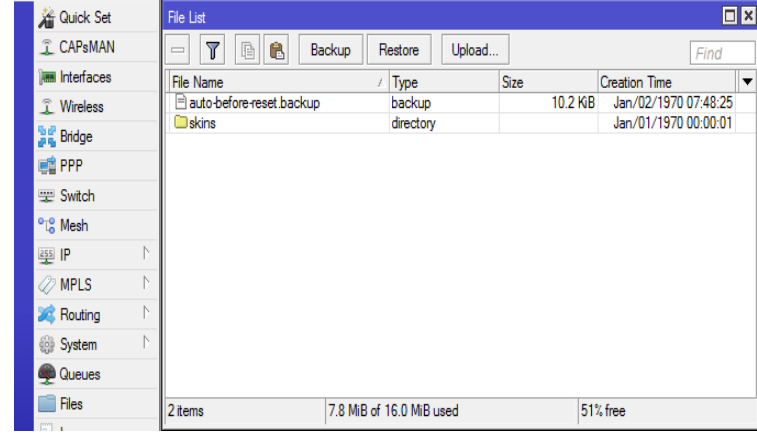

Gambar 9 backup data mikrotik

\section{Kesimpulan dan saran}

Berdasarkan pemaparan di atas, peneliti dapat menyimpulkan penelitain mengenai load balancing dengan metode ECMP ini sebagai berikut :

1. Load balancing dengan metode ECMP tidak mengakumulasi bandwidth tapi membagi beban jaringan menjadi sama rata berdasarkan perbandingan kecepatan tiap ISP.

2. Dengan dibaginya beban secara merata tiap jalur membuat performa jaringan secara keseluruhan dapat turun, namun masih dapat ditoleransi jika menggunakan layanan dari provider-provider yang baik.

3. Load balancing ECMP merupakan persistent per-connection, dengan begitu jika salah satu jalur milik ISP down, check-gateway akan memutuskan jalur tersebutdan menggunakan jalur ISP lain yang masih aktif.

4. ECMP memiliki tingkat keandalan jaringan yang tinggi jika melihat dari tingkat kehilangan data saat melakukan efek Failover. Tapi tidak pada kondisi yang ekstrim.

\section{Saran}

Dari hasil penelitian dan beberapa poin kesimpulan di atas ada beberapa saran dalam pengimplementasian penelitian ini.

1. Jika akan menggunakan load balancing dengan metode ECMP disarankan untuk menggunakan open DNS.

2. ISP pembantu disarankan yang cukup baik agar tidak terpaut jauh pada ISP utama.

3. Untuk implementasi di lapangan, disarankan menggunakan produk dengan seri RB951.

\section{Daftar Pustaka:}

Arifin. H. 2011. Kitab Suci Jaringan Komputer dan Koneksi Internet. Yogyakarta.MediaKom. 
Asyanto. Budi 2011. Perancangan dan Pembuatan Load Balancing Pada Clustering Web Server Menggunakan LVS. Studi Kasus Web Server Lemigas. UIN Syarif Hidayatullah

Hafizh. Muhammad. 2011. Load Balancing Dengan Metode Per Connection Classifier (PCC) Menggunakan Proxy Server Sebagai Caching. Studi Kasus Madrasah Tsanawiyah An-Nizhamiyyah Cileungsi. Universitas Syarif Hidayatullah. Jakarta.

Utomo. Dwi Andri. 2011. Implementasi Load Balancing Dua ISP Menggunakan Mikrotik. Studi Kasus Laboratorium Komputer SMK PGRI Bekasi. Universitas Syarif Hidayatullah. Jakarta.

Rozak, Abdul, and Ahmad Susan Pardiansyah. "Perancangan Jaringan Virtual Metametarouter." Jurnal Manajemen Informatika dan Sistem Informasi 1.1 (2018): 17-23.

Pratama. I. P. Agus Eka. 2014. Handbook Jaringan Komputer. Bandung. Informatika.
Santoso. Fajar Wahyu. 2014 Analisis Kinerja Load Balancing Menggunakan Metode Peer Connection Clasifier (PCC) Pada Pondok Pesantren Al-Jailani Yogyakarta.UIN Sunan Kalijaga.

Pitriyawati, Mahni, and Khairul Imtihan. "Sistem Informasi Kenaikan Pangkat Karyawan Pada Dinas Pekerjaan Umum (PU) Dan Energi Sumber Daya Mineral (ESDM) Kabupaten Lombok Tengah." Jurnal Manajemen Informatika dan Sistem Informasi 1.1 (2018): 31-38.

Saputra. Agung Rahmawan.2014. Analisa Perbandingan Metode Load Balancing Peer Connection Classifier (PCC) Dengan NTH Pada Router Mikrotik. UIN Sunan Kalijaga.

Yusuf. Habib Burhanudin. 2016. Skripsi Analisis Perancangan Load Balancing Dengan Metode ECMP Menggabungkan Modem ADSL Dan USB Pada Kantor Pengolahan Data Elektronik, Arsip Dan Dokumentasi Daerah Kabupaten Lombok Tengah. STMIK Amikom Yogyakarta. 